patients with nodular adrenal dysplasia stimulates adrenal cell growth in vitro, thus apparently mimicking the trophic effect of adrenocorticotrophic hormone. ${ }^{17}$

Receptor antibodies in autoimmune diseases are frequently stimulatory, as in Graves' disease, in which they mimic the effect of the endogenous hormone thyroid stimulating hormone; antibodies that inhibit the biological stimulation of the cell are, however, now well documented in hypothyroidism. ${ }^{41819}$ Our patient's antibody seems to be similar in its biological effect to these inhibitory antibodies that occur in primary hypothyroidism. We therefore suggest that in some cases at least Addison's disease may be yet another example of a receptor antibody disease.

We thank Ms M Holcombe for technical help and Dr C McMartin, Ciba Geigy, Horsham, West Sussex, for giving us the adrenocorticotrophic hormone (1-24).

\section{References}

1 Petri M, Nerup J. Addison's adrenalitis. Acta Pathol Microbiol Scand [C] 1971;79A:381-8. 2 Anderson JR, Goudie RB, Gray K, Stuart-Smith DA. Immunological features of idiopathic Addison's disease: an antibody to cells producing steroid hormones. Clin Exp Immunol 1968;3:107-17.

3 Neufeld AI, MacLaren NK, Blizzard RM. Autoimmune polyglandular syndromes. Pediatr Ann 1980;9:154-62.

Steel NR, Weightman DR, Taylor JJ, Kendall-Taylor P. Blocking activity to action of TSH in serum from patients with primary hypothyroidism. Br Med 7 1984;288:1559-62.

5 Weightman DR, Shale DJ, Tomlinson WR. A rapid radioassay for human IgG produced in lymphocyte in vitro culture systems. F Immunol Methods 1981;146:307-12.
6 Lambert A, Frost J, Garner C, Robertson WR. Cortisol production by dispersed guinea-pig adrenal cells: a specific, sensitive and reproducible response to ACTH and its fragments. I Steroid Biochem $1984 ; 21: 157-62$.

7 Oliver JR, Hakendorf P, Zeegers P, Ross W. A proposed simple method for detection and measurement of antibodies to insulin in serum by use of Staphylococcus aureus containing protein A. Clin Chem 1982;28:121-3.

8 Spinner MW, Blizzard RM, Gibbs J, Abbey H, Childs B. Familial distributions of organ-specific antibodies in the blood of patients with Addison's disease and hypoparathyroidism and their relatives. Clin Exp Immunol 1969;5:461-8.

9 Whitaker J, Landing BH, Esselborn VM, Williams RR. Syndrome of familial juvenile hypoadrenocorticism, hypoparathyroidism and superficial moniliasis. 7 Clin Endocrino 1956;16:1374-87.

10 Arulanantham K, Dwyer JM, Genel M. Evidence for defective immunoregulation in the syndrome of familial candidiasis. $N$ Engl f Med 1979;300:164-8.

11 MacLaren NK, Riley WJ. Inherited susceptibility to autoimmune Addison's disease is linked to human leukocyte antigens-DR3 and/or DR4, except when associated with Type I autoimmune polyglandular syndrome. 7 Clin Endocrinol Metab 1986;62:455-9.

12 Runcie CJ, Semple CG, Slater SD. Addison's disease without pigmentation. Scott Med $\mathcal{f}$ 1986;31:111-2.

13 Chiauzzi V, Cigorraga S, Escobar ME, et al. Inhibition of FSH receptor binding by circulating immunoglobulins. I Clin Endocrinol Metab 1982;54:1221-7.

14 de Aizpurua HJ, Ungar B, Toh BH. Autoantibody to the gastrin receptor in pernicious anaemia. N Engl f Med 1985;313:479-83.

15 Blecher M. Receptors, antibodies, and disease. Clin Chem 1984;30:1137-56.

6 Laird SM, Vinson GP. Monoclonal antibodies against rat adrenocortical plasma membrane antigens. F Endocrinol 1987;112(suppl):270.

17 Teding van Berkhout F, Croughs RJM, Kater L, et al. Familial Cushing's syndrome due to nodular adrenocortical dysphasia. A putative receptor antibody disease. $\mathcal{F}$ Clin Endocrino 1986;24:299-310.

18 Konishi J, Iida Y, Endo K, et al. Inhibition of thyrotropin-induced adenosine 3' 5'monophosphate increase by immunoglobulins from patients with primary myxoedema. $f \mathrm{Clin}$ Endocrinol Metab 1983;57:544-9.

19 Takasu N, Yamada T, Katakura M, Yamauchi K, Shimuzu Y, Ishizuki Y. Evidence for thyrotrophin (TSH)-binding activity in goitrous Hashimoto's thyroiditis with assays measuring inhibition of TSH receptor binding and TSH-stimulated thyroid adenosine $3^{\prime} 5^{\prime}$-monoinhibition of TSH receptor binding and TSH-stimulated thyroid adenosine 3 '-mono-
phosphate responses/cell growth by immunoglobulins. I Clin Endocrinol Metab 1987;64: 239-45.

(Accepted 14 January 1988)

\title{
Paranormal healing and hypertension
}

\author{
JAAP J BEUTLER, JOHANNES T M ATTEVELT, SYBO A SCHOUTEN, JOOP A J FABER, \\ EVERT J DORHOUT MEES, GIJSBERT G GEIJSKES
}

\begin{abstract}
A prospective randomised trial was carried out to see whether paranormal healing by laying on of hands might reduce blood pressure in essential hypertension and whether such an effect might be due to a paranormal, psychological, or placebo factor. Patients were randomised to three treatment groups: paranormal healing by laying on of hands $(n=40)$, paranormal healing at a distance $(n=37)$, and no paranormal healing (controls; $n=38$ ). Healing at a distance and no paranormal healing were investigated double blind. Systolic and diastolic blood pressures were significantly reduced in all three groups at week 15 (mean reduction $(95 \%$
\end{abstract}

Department of Nephrology and Hypertension, University Hospital, Utrecht, 3511 GV Utrecht, The Netherlands

JAAP J BEUTLER, MD, research fellow

EVERT J DORHOUT MEES, MD, professor of nephrology

GIJSBERT G GEIJSKES, MD, senior consultant

Department of Social Sciences, State University, Utrecht, 3584 CA Utrecht, The Netherlands

JOHANNES T M ATTEVELT, research fellow and psychologist

SYBO A SCHOUTEN, PHD, senior lecturer

Institute of Mathematical Statistics, State University, Utrecht, 3508 TA

Utrecht, The Netherlands

JOOP A J FABER, PHD, statistician

Correspondence and requests for reprints to: Dr Beutler. confidence interval) $17 \cdot 1(14.0$ to $20 \cdot 2) / 8 \cdot 3(6.6$ to $10 \cdot 0) \mathrm{mm} \mathrm{Hg}$ ). Only the successive reductions in diastolic blood pressures among the groups from week to week were significantly different. Each week diastolic pressure was consistently lower (average 1.9 $\mathrm{mm} \mathbf{H g}$ ) after healing at a distance compared with control, but on paired comparison these differences were not significant. Probably week to week variations among the groups accounted for any differences noted.

In this study no treatment was consistently better than another and the data cannot therefore be taken as evidence of a paranormal effect on blood pressure. Probably the fall in blood pressure in all three groups either was caused by the psychosocial approach or was a placebo effect of the trial itself.

\section{Introduction}

Paranormal healing has been used in the treatment of various diseases for centuries and has a long tradition reaching back into Christianity and spiritualism. ${ }^{1}$ It has become increasingly popular in the United Kingdom and The Netherlands..$^{2.5}$ In one year 65000 patients were seen by 600 healers in The Netherlands, resulting in some 2 million patient consultations. ${ }^{6}$ Paranormal healing is performed in two main ways - by laying on of hands and by healing at a distance, in which the healer takes a patient in mind and healing occurs by thought projection. In a previous study most patients (85\%) claimed improvement after paranormal treatment. ${ }^{2}$ To our knowledge, however, no data are available on whether paranormal healing results in measurable improvement. We have therefore investigated whether laying on of hands might reduce blood pressure and whether 
such an effect might be due to a placebo, paranormal, or psychological factor. Paranormal and placebo effects were investigated double blind.

\section{Patients and methods}

The first 1200 of over 2000 patients with essential hypertension who responded to one advertisement in several national newspapers were sent information about the trial, a consent form to participate, and a form to allow us to obtain information from their general practitioners. Patients were also asked to complete a 30 item questionnaire asking about their past medical history, possible known causes of their hypertension-for example, renal disease-current treatment, and complications especially ischaemic heart disease, heart failure, cerebrovascular accidents, and other vascular disease. The questionnaire also asked about intercurrent diseases-for example, diabetes mellitus—and for the results of the last blood pressure measurement. After receiving permission we sent a comparable questionnaire to their doctors.

Five hundred and eighty seven questionnaires were returned. Based on these, 200 patients were selected who had a systolic blood pressure of $140 \mathrm{~mm}$ $\mathrm{Hg}$ or above or a diastolic pressure of $90 \mathrm{~mm} \mathrm{Hg}$ or above (World Health Organisation criteria for hypertension), or both, without or despite antihypertensive treatment and in whom there were no complications of hypertension and none of the diseases mentioned above. ${ }^{7}$ These patients were invited for screening and at the screening visit were seen by one of us (JJB). Blood pressure criteria for entry to the trial were the same as those used in the selection for screening. Screening blood pressure was defined as the mean of the last two readings of at least three recordings by automatic oscillometry. Recording was continued until the last two readings showed a difference of less than $10 \mathrm{~mm} \mathrm{Hg}$ systolic and $5 \mathrm{~mm} \mathrm{Hg}$ diastolic (Omega 1400 with printer, Invivo Research Laboratories, Broken Arrow, Oklahoma). During the screening visit a medical history was taken, including the type and dose of antihypertensive treatment and use of a salt restricted diet, and a physical examination performed. Biochemical studies comprised measurement of plasma creatinine concentration and urinary dipstick analysis (Combur-7. Test, Boehringer Mannheim). Standard electrocardiography was performed.

Of the 200 patients screened, 64 were excluded from the trial for the following reasons: too great an arm circumference for proper measurement (two patients), pressures below entry criteria (38), bronchial asthma (five), glucosuria (two), proteinuria (two), cardiomyopathy (one), aortic stenosis (one), heart failure (one), atrial fibrillation (one), electrocardiographic signs of ischaemic heart disease (two), renal failure (one), and a history or probability of non-compliance (eight). Evidence of left ventricular hypertrophy in the electrocardiogram was not a reason for exclusion.

There were therefore 136 eligible patients with uncomplicated essential hypertension, of whom the 120 with the highest diastolic pressures were selected for the trial. Eighty one of these patients were taking antihypertensive drugs. Patients were instructed to continue with the treatment schedule and diet prescribed by their doctors. Written and verbal informed consent was obtained from each participant.

After the three weeks of medical selection the 120 participants were grouped into threes with comparable diastolic blood pressures as obtained at the screening visit. Patients taking and not taking antihypertensive drugs were grouped into separate triplets. The three study treatments were then randomly assigned within each set of triplets, as follows: group 1 received healing by laying on of hands, during which verbal communication was allowed: group 2 received healing at a distance; and group 3 received no healing and served as a control for group 2. Patients in groups 2 and 3 sat behind a one way screen and were blinded to treatment; we also were unaware of which treatment they received, and these patients were therefore studied double blind.

The study was based on the hypothesis that a difference in blood pressure after laying on of hands might be a placebo effect, a paranormal effect, a psychological effect, or a combination of the three. A difference in blood pressure after healing at a distance compared with control could be caused only by a paranormal factor. The difference in change of blood pressure between patients treated by laying on of hands and healing at a distance might be ascribed to an additional psychological effect elicited by patient-healer contact (fig 1).

Treatment was given as a 20 minute session one morning a week for 15 weeks. At the start (week 0 ) no treatment was given and only measurements were done and pretreatment values obtained. Patients were monitored by closed circuit video recording. Blood pressure readings were taken by a paramedical worker before and after each session on the right arm in a sitting position. The same method was used as during screening. The mean value of the last two readings was used for data analysis. During measurements and treatment background music was played. A doctor was available for patient consultations and reviewed the blood pressure levels of each patient. When blood pressure rose above $200 \mathrm{~mm} \mathrm{Hg}$ systolic and $125 \mathrm{~mm} \mathrm{Hg}$ diastolic the patient was advised to consult his or her own doctor (this occurred in one case, though the patient preferred to continue with the study). Every four weeks any change in medication and diet was checked by means of a questionnaire (four questions) that assessed the type and amount of medication and whether the patient was taking a salt restricted diet. The results were compared with the information obtained at screening. At the end of the study patients also completed a questionnaire on general wellbeing, recorded as much improved (healed); moderately, slightly, and not improved; and slightly, moderately, and strongly deteriorated.

Twelve well known healers acquainted with both forms of treatment were selected from several Dutch societies of paranormal healing and assigned to the 80 patients in groups 1 and 2.

\section{STATISTICAL ANALYSIS}

Results are expressed as mean values and $95 \%$ confidence intervals. Several patients could not be included in the analysis. Five patients failed to adhere to the protocol and three were substituted for three others who withdrew from the study after randomisation but before treatment. This resulted in the loss of eight triplets (24 patients). Multivariate analysis of variance was applied on the successive reductions or weekly changes in blood pressures and heart rate over the 15 weeks in the 32 complete triplets. Because of the availability of 115 patients, the matching of patients on screening instead of pretreatment values, and the absence of influence of triplets on blood pressure we felt justified in reanalysing the data, ignoring triplets, for all the 115 patients who followed the protocol. Differences in baseline characteristics among groups and in reductions in blood pressure at the end of the study as compared with pretreatment values were analysed by univariate analysis of variance. Analyses were carried out with and without covariates, such as the influence of age and use of antihypertensive treatment on reductions in blood pressure. For paired comparisons we used Bonferroni's technique to protect against having too many significant differences. Improvement in general wellbeing was analysed by Kruskal-Wallis analysis of variance and paired comparisons by the Wilcoxon rank sum test. Correlation between a reduction in blood pressure and improved wellbeing was analysed by Spearman rank order correlations.

\section{Results}

The three treatment groups were similar in baseline characteristics except age (table I). There was also no significant difference among the groups when stratified by patients taking and not taking antihypertensive agents (table II). The mean duration of hypertension in the whole series was 12.9 years.

There were only two instances of a possible adverse reaction to treatment; one patient reported transient headache and another experienced a bout of crying. Three patients withdrew after randomisation but before treatment and were replaced by three others. Two patients withdrew during the treatment period; one in group 2 (healing at a distance) was pregnant, and one of the controls was disappointed not to be in the group treated by laying on of hands. Blood pressure measurements in one patient in group 3 were technically inadequate. Two patients in the healing at a distance group missed more than six sessions and were excluded from analysis. After the loss of these patients (and therefore eight triplets) we found in the remaining 96 (32 triplets) no differences among groups in systolic and diastolic blood pressures and heart rate during the 15 weeks. As there was no influence of triplets on blood pressure $(p=0 \cdot 70)$ our further results are presented for all 115 patients who adhered to the protocol.

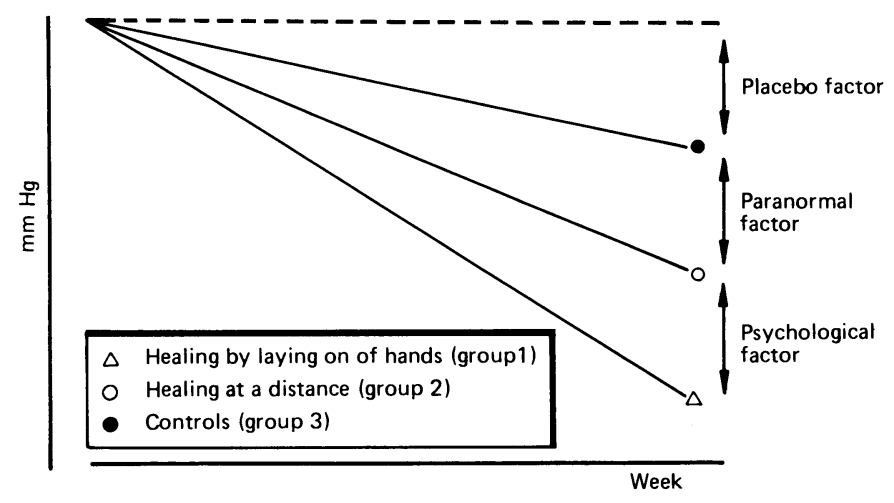

FIG 1-Hypothesis used in study of paranormal treatment of essential hypertension. 
TABLE I-Mean baseline values (95\% confidence intervals) of patients treated by laying on of hands (group 1) and healing at a distance (group 2) and of patients who received no healing (controls; group 3)

\begin{tabular}{|c|c|c|c|c|}
\hline & $\begin{array}{l}\text { Group 1 } \\
(n=40)\end{array}$ & $\begin{array}{l}\text { Group 2 } \\
(n=40)\end{array}$ & $\begin{array}{c}\text { Group } 3 \\
(n=40)\end{array}$ & p Value \\
\hline Age (years) & $\begin{array}{c}53 \cdot 1 \\
(50 \cdot 4-55 \cdot 8)\end{array}$ & $\begin{array}{c}48 \cdot 3 \\
(45 \cdot 5-51 \cdot 1)\end{array}$ & $\begin{array}{c}50 \cdot 6 \\
(47 \cdot 7-53 \cdot 5)\end{array}$ & $\mathrm{p}=0.05$ \\
\hline No of men/women & $19 / 21$ & $23 / 17$ & $26 / 14$ & NS \\
\hline Body weight $(\mathrm{kg})$ & $\begin{array}{c}76 \cdot 1 \\
(72 \cdot 1-80 \cdot 1)\end{array}$ & $\begin{array}{c}76 \cdot 3 \\
(72 \cdot 3-80 \cdot 3)\end{array}$ & $\begin{array}{c}76 \cdot 6 \\
(73 \cdot 2-80 \cdot 0)\end{array}$ & NS \\
\hline Heart rate (beats/min) & $\begin{array}{c}77 \cdot 4 \\
(72 \cdot 9-81 \cdot 9)\end{array}$ & $\begin{array}{c}80 \cdot 5 \\
(76 \cdot 0-85 \cdot 0)\end{array}$ & $\begin{array}{c}75 \cdot 3 \\
(70 \cdot 5-80 \cdot 1)\end{array}$ & NS \\
\hline Systolic blood pressure $(\mathrm{mm} \mathrm{Hg})$ & $\begin{array}{c}164 \cdot 5 \\
(158 \cdot 1-170 \cdot 9)\end{array}$ & $\begin{array}{c}163 \cdot 0 \\
(158 \cdot 5-167 \cdot 5)\end{array}$ & $\begin{array}{c}167 \cdot 8 \\
(161 \cdot 6-174 \cdot 0)\end{array}$ & NS \\
\hline Diastolic blood pressure $(\mathrm{mm} \mathrm{Hg})$ & $\begin{array}{c}100 \cdot 6 \\
(97 \cdot 9-103 \cdot 3)\end{array}$ & $\begin{array}{c}100 \cdot 0 \\
(97 \cdot 7-102 \cdot 3)\end{array}$ & $\begin{array}{c}100 \cdot 1 \\
(97 \cdot 5-102 \cdot 7)\end{array}$ & NS \\
\hline
\end{tabular}

Between screening and the start of treatment (week $-3 v$ week 0 ) all three groups showed a reduction in systolic and diastolic blood pressures; $(p<0.05$; fig 2). The reduction did not differ significantly among the groups. Mean reductions in systolic and diastolic pressures were $12.6(95 \%$ confidence interval 9.7 to 15.5$)$ and $4.7(3.0$ to 6.4$) \mathrm{mm} \mathrm{Hg}$ respectively (see table III). Reductions in heart rate did not differ significantly among the three groups (mean reduction $4 \cdot 1$ beats $/ \mathrm{min}$ ). The decline in systolic and diastolic pressures among the three groups stratified by patients taking and not taking antihypertensive drugs also showed no significant difference (see table III). The same significant $(\mathrm{p}<0.05)$ reduction in blood pressures was achieved in these subgroups with the exception of the systolic and diastolic pressures of patients not receiving antihypertensive agents in group 1 and the diastolic pressure of patients not given these drugs in group 2 .

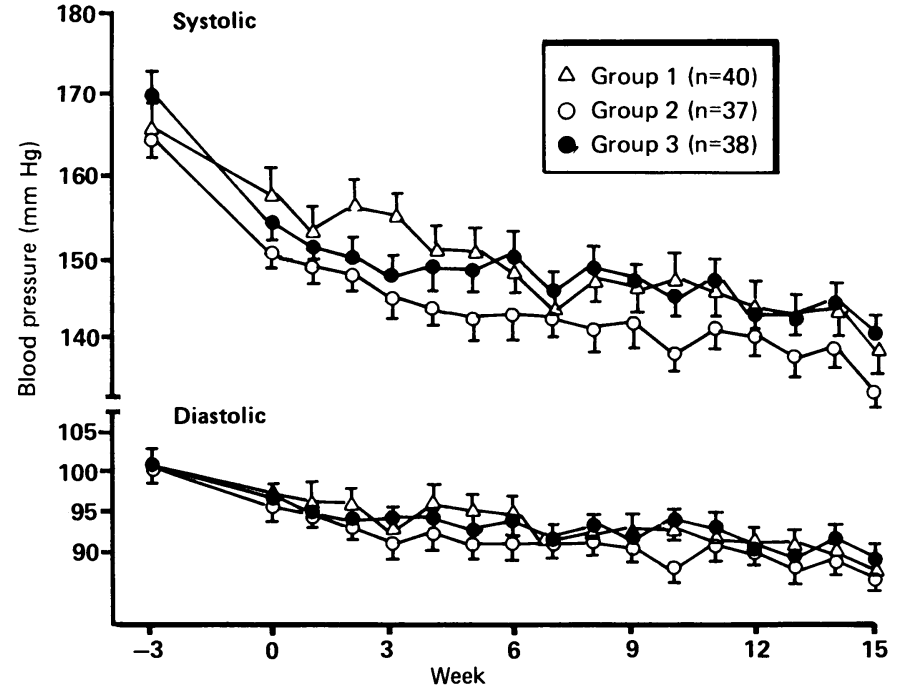

FIG 2-Mean systolic and diastolic blood pressures in the three study groups at screening (week -3 ), before treatment (week 0 ), and during subsequent 15 weeks. Bars are SEM.

different, despite the non-significant reductions in systolic and diastolic pressures in patients not taking antihypertensive drugs in group 3 (table III).

Analysis of successive reductions in systolic and diastolic blood pressures among the three groups showed significant differences $(p<0 \cdot 05)$ only for

TABLE II-Mean baseline blood Dressures (95\% confidence intervals) in the three study groups stratified by patients taking and not taking antihypertensive agents

\begin{tabular}{|c|c|c|c|c|c|c|c|}
\hline & \multicolumn{3}{|c|}{ Patients taking antihypertensive drugs $(n=81)$} & \multicolumn{3}{|c|}{ Patients not taking antihypertensive drugs $(n=39)$} & \multirow[b]{2}{*}{ p Value } \\
\hline & $\begin{array}{c}\text { Group 1 } \\
(n=26)\end{array}$ & $\begin{array}{c}\text { Group 2 } \\
(n=26)\end{array}$ & $\begin{array}{c}\text { Group } 3 \\
(n=29)\end{array}$ & $\begin{array}{c}\text { Group 1 } \\
(n=14)\end{array}$ & $\begin{array}{c}\text { Group 2 } \\
(n=14)\end{array}$ & $\begin{array}{c}\text { Group } 3 \\
(n=11)\end{array}$ & \\
\hline Systolic blood pressure $(\mathrm{mm} \mathrm{Hg})$ & $\begin{array}{c}168 \cdot 8 \\
(161 \cdot 0-176 \cdot 6)\end{array}$ & $\begin{array}{c}164 \cdot 8 \\
(159 \cdot 4-170 \cdot 2)\end{array}$ & $\begin{array}{c}169 \cdot 4 \\
(161 \cdot 4-177 \cdot 4)\end{array}$ & $\begin{array}{c}156 \cdot 6 \\
(146 \cdot 6-166 \cdot 6)\end{array}$ & $\begin{array}{c}159 \cdot 4 \\
(151 \cdot 7-167 \cdot 1)\end{array}$ & $\begin{array}{c}163 \cdot 7 \\
(157 \cdot 0-170 \cdot 4)\end{array}$ & NS \\
\hline Diastolic blood pressure $(\mathrm{mm} \mathrm{Hg})$ & $\begin{array}{c}101 \cdot 4 \\
(98 \cdot 0-104 \cdot 8)\end{array}$ & $\begin{array}{c}101 \cdot 5 \\
(98 \cdot 7-104 \cdot 3)\end{array}$ & $\begin{array}{c}99 \cdot 8 \\
(96 \cdot 7-102 \cdot 9)\end{array}$ & $\begin{array}{c}98 \cdot 6 \\
(94 \cdot 7-102 \cdot 5)\end{array}$ & $\begin{array}{c}97 \cdot 1 \\
(93 \cdot 9-100 \cdot 3)\end{array}$ & $\begin{array}{c}100 \cdot 5 \\
(95 \cdot 2-105 \cdot 8)\end{array}$ & NS \\
\hline
\end{tabular}

During the 15 weeks of treatment a further fall in systolic and diastolic blood pressures occurred in all three groups (week $0 v$ week 15: $\mathrm{p}<0.001$; fig 2 , table III). The mean falls in systolic pressure in groups 1,2 , and 3 were $19 \cdot 3(95 \%$ confidence interval $13 \cdot 7$ to $24 \cdot 9), 17 \cdot 5(12 \cdot 5$ to $22 \cdot 5)$, and $14 \cdot 2$ $(8 \cdot 3$ to $20 \cdot 1) \mathrm{mm} \mathrm{Hg}$ respectively, and the corresponding falls in diastolic pressure were $9 \cdot 4(6 \cdot 1$ to $12 \cdot 7), 8 \cdot 6(5 \cdot 9$ to $11 \cdot 3)$, and $6 \cdot 7(4 \cdot 0$ to $9 \cdot 4) \mathrm{mm} \mathrm{Hg}$ (table III). The overall mean falls in systolic and diastolic pressures for all 115 patients were $17 \cdot 1(14.0$ to $20 \cdot 2)$ and $8 \cdot 3(6.6$ to $10 \cdot 0) \mathrm{mm} \mathrm{Hg}$ respectively. These data were also analysed separately for the subgroups of patients taking and not taking antihypertensive drugs (table III). At week 15 the falls in blood pressure among the subgroups were not significantly diastolic pressure. Paired comparison among groups for systolic and diastolic pressures, however, yielded no significant differences. Though the mean diastolic blood pressure in group 2 was consistently lower than in group 3 (by an average of $1.9 \mathrm{~mm} \mathrm{Hg}$ ), this was not significant (fig 3 ). The difference in ages among the groups did not influence the reduction in diastolic blood pressure. During the 15 weeks of treatment there was no significant difference in diastolic pressures among the groups stratified by patients taking and not taking antihypertensive drugs. Heart rate remained unchanged and showed no differences among the groups.

Within session differences among the groups were seen only for diastolic blood pressure $(\mathrm{p}<0.0001)$. Immediately after paranormal healing by laying

TABLE III-Mean reductions in blood pressure (95\% confidence intervals) between screening and start of treatment (week $-3 v$ week 0 ) and start and end of treatment (week $0 v$ week 15) for all patients and for patients stratified by study group and whether they were receiving antihypertensive drugs

\begin{tabular}{|c|c|c|c|c|c|c|c|c|c|c|}
\hline & \multicolumn{4}{|c|}{ All patients $(n=115)$} & \multicolumn{3}{|c|}{$\begin{array}{l}\text { Patients taking antihypertensive } \\
\text { drugs }(\mathrm{n}=78)\end{array}$} & \multicolumn{3}{|c|}{$\begin{array}{l}\text { Patients not taking antihypertensive } \\
\text { drugs }(\mathrm{n}=37)\end{array}$} \\
\hline & $\underset{(n=115)}{\text { All }}$ & $\begin{array}{c}\text { Group 1 } \\
(n=40)\end{array}$ & $\begin{array}{c}\text { Group } 2 \\
(n=37)\end{array}$ & $\begin{array}{c}\text { Group } 3 \\
(\mathrm{n}=38)\end{array}$ & $\underset{(n=26)}{\text { Group } 1}$ & $\underset{(n=24)}{\text { Group 2 }}$ & $\begin{array}{c}\text { Group } 3 \\
(n=28)\end{array}$ & $\begin{array}{c}\text { Group } 1 \\
(n=14)\end{array}$ & $\underset{(n=13)}{\text { Group } 2}$ & $\begin{array}{c}\text { Group } 3 \\
(n=10)\end{array}$ \\
\hline \multicolumn{11}{|l|}{ Week $-3 v$ week $0:$} \\
\hline Systolic blood pressure $(\mathrm{mm} \mathrm{Hg}$ ) & $\begin{array}{c}12 \cdot 6 \\
(9 \cdot 7-15 \cdot 5)\end{array}$ & $\begin{array}{c}8 \cdot 3 \\
(2 \cdot 7-13 \cdot 9)\end{array}$ & $\begin{array}{c}13 \cdot 9 \\
(9 \cdot 1-18 \cdot 7)\end{array}$ & $\begin{array}{c}15 \cdot 7 \\
(10 \cdot 9-20 \cdot 5)\end{array}$ & $\begin{array}{c}10 \cdot 3 \\
(2 \cdot 7-17 \cdot 9)\end{array}$ & $\begin{array}{c}17 \cdot 9 \\
(11 \cdot 7-24 \cdot 1)\end{array}$ & $\begin{array}{c}15 \cdot 8 \\
(9 \cdot 7-21 \cdot 9)\end{array}$ & $\begin{array}{c}4 \cdot 7 \\
(-4 \cdot 1-13 \cdot 5)\end{array}$ & $\begin{array}{c}6 \cdot 5 \\
(0 \cdot 3-12 \cdot 7)\end{array}$ & $\begin{array}{c}15 \cdot 7 \\
(7 \cdot 7-23 \cdot 7)\end{array}$ \\
\hline Diastolic blood pressure $(\mathrm{mm} \mathrm{Hg})$ & $\begin{array}{c}4 \cdot 7 \\
(3 \cdot 0-6 \cdot 4)\end{array}$ & $\begin{array}{c}4 \cdot 0 \\
(1 \cdot 1-6 \cdot 9)\end{array}$ & $\begin{array}{c}5 \cdot 0 \\
(1 \cdot 6-8 \cdot 4)\end{array}$ & $\begin{array}{c}5 \cdot 1 \\
(2 \cdot 5-7 \cdot 7)\end{array}$ & $\begin{array}{c}4 \cdot 3 \\
(0 \cdot 6-8 \cdot 0)\end{array}$ & $\begin{array}{c}7 \cdot 4 \\
(2 \cdot 5-12 \cdot 3)\end{array}$ & $\begin{array}{c}4 \cdot 4 \\
(0 \cdot 9-3 \cdot 5)\end{array}$ & $\begin{array}{c}3 \cdot 4 \\
(-1 \cdot 4-8 \cdot 2)\end{array}$ & $\begin{array}{c}0 \cdot 5 \\
(-1 \cdot 6-2 \cdot 6)\end{array}$ & $\begin{array}{c}7 \cdot 0 \\
(4 \cdot 6-9 \cdot 4)\end{array}$ \\
\hline \multicolumn{11}{|l|}{ Week $0 v$ week $15:$} \\
\hline Systolic blood pressure $(\mathrm{mm} \mathrm{Hg})$ & $\begin{array}{c}17 \cdot 1 \\
(14 \cdot 0-20 \cdot 2)\end{array}$ & $\begin{array}{c}19 \cdot 3 \\
(13 \cdot 7-24 \cdot 9)\end{array}$ & $\begin{array}{c}17 \cdot 5 \\
(12 \cdot 5-22 \cdot 5)\end{array}$ & $\begin{array}{c}14 \cdot 2 \\
(8 \cdot 3-20 \cdot 1)\end{array}$ & $\begin{array}{c}19 \cdot 2 \\
(12 \cdot 4-26 \cdot 0)\end{array}$ & $\begin{array}{c}16 \cdot 7 \\
(11 \cdot 7-21 \cdot 7)\end{array}$ & $\begin{array}{c}17 \cdot 2 \\
(10 \cdot 2-24 \cdot 1)\end{array}$ & $\begin{array}{c}19 \cdot 4 \\
(8 \cdot 5-30 \cdot 3)\end{array}$ & $\begin{array}{c}19 \cdot 1 \\
(7 \cdot 2-31 \cdot 0)\end{array}$ & $\begin{array}{c}5 \cdot 9 \\
(-5 \cdot 1-16 \cdot 9)\end{array}$ \\
\hline Diastolic blood pressure $(\mathrm{mm} \mathrm{Hg})$ & $\begin{array}{c}8 \cdot 3 \\
(6 \cdot 6-10 \cdot 0)\end{array}$ & $\begin{array}{c}9 \cdot 4 \\
(6 \cdot 1-12 \cdot 7)\end{array}$ & $\begin{array}{c}8 \cdot 6 \\
(5 \cdot 9-11 \cdot 3)\end{array}$ & $\begin{array}{c}6 \cdot 7 \\
(4 \cdot 0-9 \cdot 4)\end{array}$ & $\begin{array}{c}9 \cdot 8 \\
(5 \cdot 8-13 \cdot 8)\end{array}$ & $\begin{array}{c}8 \cdot 9 \\
(5 \cdot 5-12 \cdot 3)\end{array}$ & $\begin{array}{c}7 \cdot 6 \\
(4 \cdot 5-10 \cdot 7)\end{array}$ & $\begin{array}{c}8 \cdot 6 \\
(1 \cdot 8-15 \cdot 4)\end{array}$ & $\begin{array}{c}8 \cdot 1 \\
(3 \cdot 2-13 \cdot 0)\end{array}$ & $\begin{array}{c}4 \cdot 3 \\
(-1 \cdot 8-10 \cdot 4)\end{array}$ \\
\hline
\end{tabular}


on of hands the diastolic blood pressure rose significantly $(p<0.05)$ by an average of $1.8 \mathrm{~mm} \mathrm{Hg}$. There was a reduction in heart rate immediately after each session $(p<0.05)$ in each group (average reduction 2.9 beats $/ \mathrm{min}$ ).

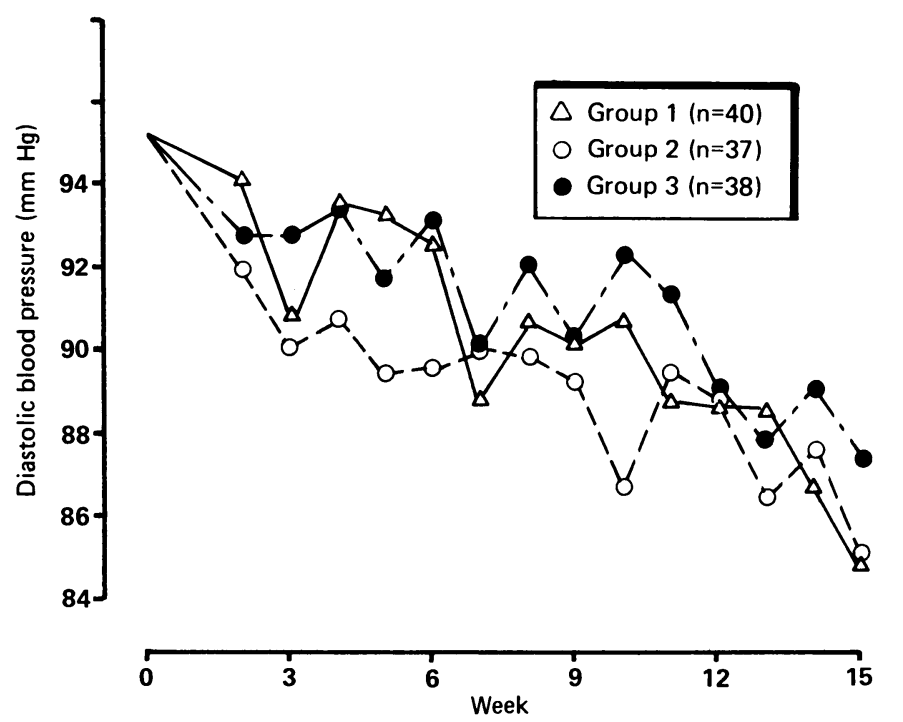

FIG 3-Mean diastolic blood pressures in the three study groups during the 15 weeks with pretreatment values as covariate.

Because of logistic problems only 84 of the 115 patients completed the questionnaire on general wellbeing at the end of the study. (We thought it inappropriate to allow the missing subjects to complete the questionnaire at a different time interval after the study.) After 15 weeks of treatment $30(83 \%)$ of the 36 patients in group 1 felt improved compared with $9(43 \%)$ of the 21 in group 2 and $11(41 \%)$ of the 27 in group $3(p<0.005)$. No patient felt worse (table IV). There was no correlation between improved wellbeing and the reduction in blood pressure.

TABLE IV-Results of questionnaire on general wellbeing at end of 15 weeks in the three study groups of patients (only 84 patients completed questionnaire)

\begin{tabular}{|c|c|c|c|c|c|c|}
\hline & \multicolumn{2}{|c|}{ Group 1} & \multicolumn{2}{|c|}{ Group 2} & \multicolumn{2}{|c|}{ Group 3} \\
\hline & No & $\%$ & No & $\%$ & No & $\%$ \\
\hline Much improved & 4 & $11 \cdot 1$ & 0 & 0 & 1 & $3 \cdot 7$ \\
\hline Moderately & 16 & $44 \cdot 4$ & 3 & $14 \cdot 3$ & 5 & $18 \cdot 5$ \\
\hline Slightly improved & 10 & $27 \cdot 8$ & 6 & 28.6 & 5 & $18 \cdot 5$ \\
\hline Not improved & 6 & $16 \cdot 7$ & 12 & $57 \cdot 1$ & 16 & $59 \cdot 3$ \\
\hline Deteriorated & 0 & 0 & 0 & 0 & 0 & 0 \\
\hline Total & 36 & $100 \cdot 0$ & 21 & $100 \cdot 0$ & 27 & $100 \cdot 0$ \\
\hline
\end{tabular}

Significance of differences among groups $\mathrm{p}<0 \cdot 001$. (Group $1 v$ group $3, \mathrm{p}<0.001$; group $2 v$ group 3, NS; group $1 v$ group 2, p<0.05.)

\section{Discussion}

That over 2000 people replied to a single advertisement about the trial in several national newspapers confirms the growing interest in paranormal healing. ${ }^{2.5}$

The fall in blood pressures and heart rate that occurred between enrolment in the trial and the start of treatment may have been due to an alarm reaction caused by a doctor measuring the blood pressure during physical examination followed by regression to the mean ${ }^{89}$ During the rest of the study blood pressure was taken by paramedical staff. We had expected that the atmosphere created by a healer would elicit the same phenomenon as the relaxation response. ${ }^{10}$ Diastolic blood pressure, however, was increased immediately after each session of healing by laying on of hands, though diastolic pressures measured before each session fell during the 15 weeks of treatment (fig 2). Significant differences among the groups were found only for the successive reductions in diastolic blood pressure. Each week the diastolic pressure was consistently lower in the patients treated by healing at a distance compared with controls (fig 3). Though paired comparison yielded no significant difference, the reduction may indicate a paranormal influence.

Our hypothesis (fig 1) was that if blood pressures were decreased after paranormal healing by laying on of hands this might be due to a combination of placebo, paranormal, and psychological factors. A difference in blood pressure after healing at a distance compared with control could be caused only by a paranormal factor. Any difference in the reduction of blood pressure between patients treated by laying on of hands and at a distance might be ascribed to a psychological factor. We have no evidence that any one treatment was better than another. The fall in blood pressure in all three groups at week 15 was probably a placebo effect. The higher diastolic blood pressures in the first weeks after laying on of hands and the week to week variations among groups probably caused the significant differences among the three groups. This effect was not consistent during the 15 weeks. The higher diastolic blood pressures in the first weeks agree with the quoted experience of healers.

The mean falls in systolic and diastolic blood pressures during the 15 weeks of treatment $(17 \cdot 1$ and $8.3 \mathrm{~mm} \mathrm{Hg}$ respectively) were greater than expected. Probably this was due to the psychosocial approach and may be of medical interest. The mechanisms of psychosocial and placebo factors remain unclear. As patients selected for the trial had replied to a newspaper advertisement they presumably favoured alternative medicine, which might have had a positive effect on the reduction in blood pressure. Furthermore, the study ran from February to June, so that the increase in temperature may also have played a part. ${ }^{11}$

Based on our hypothesis the rise in diastolic blood pressure immediately after laying on of hands was due to a psychological and not a paranormal factor because no within session differences were observed in the other groups. This psychological factor may, for instance, have been the emotions elicited in the direct contact between healer and patient. The within session fall in heart rate, which was the same in all three groups, was presumably a placebo effect.

The improved wellbeing after laying on of hands must also have been a psychological, not a paranormal effect because no difference in wellbeing was found between healing at a distance and control. This finding was not unexpected and presumably was the result of direct contact between healer and patient. It probably explains the popularity of this method of treatment.

We conclude that paranormal healing is safe in complementary medicine but that there is little evidence for an effect of a paranormal factor. The fall in blood pressure in all three groups was probably caused by the psychosocial approach or was a placebo effect of the trial itself.

This study was supported by the Dutch Research Foundation for Paranormal Healing. We also thank the Dutch Ministry of Health for taking the initiative for the study, A J de Meijer for the statistical analysis, and all the paranormal healers who had the courage to take part.

\section{References}

1 Anonymous. Exploring the effectiveness of healing [Editorial]. Lancet 1985;ii:1177-8.

2 Attevelt JTM. Paranormal healing. Utrecht: State University Utrecht, 1988:47. (Dissertation.)

3 Reilly DT. Young doctors' view on alternative medicine. Br Med 7 1983;287:337-9.

4 Fulder SJ, Munro RE. Complementary medicine in the United Kingdom: patients, practitioners, ulder SJ, Munro RE. Complementary medit
and consultations. Lancet 1985 ;ii:542-5.

5 Limburger HHB, Mackenbach JP, Ooyendijk WTM. Het gebruik van alternatieve geneeswijzen in Nederland. Tijdschrift voor Sociale Geneeskunde 1981;7:219-25.

6 Hage H. Zou ik per se in een dokter moeten geloven, en niet in een paranormale genezer? Toegepaste Wetenschap TNO (Nederlandse Organisatie voor Toegepast-Natuurwetenschappelijk Onderzoek) 1986;2:37-40.

7 WHO Expert Committee. Arterial hypertension. WHO Tech Rep Ser 1978; No 628

8 Mancia G, Bertiniere G, Grassi G, et al. Effect of blood-pressure measurement by the doctor on patients' blood pressure and heart rate. Lancet 1983;ii:695-8.

9 Shepard DS, Finison LJ. Blood pressure reductions: correcting for regression to the mean. Prev Med 1983;12:304-17.

10 Benson H. Systemic hypertension and the relaxation response. Lancet 1977; ;:1152-6.

11 Brennan PJ, Greenberg G, Miall WE, Thompson SG. Seasonal variation in arterial blood pressure. Br Med f 1982;285:919-23.

(Accepted 26 fanuary 1988) 